\title{
The COMPLEX NATURE OF AUTONOMY
}

(A natureza complexa da autonomia)

\author{
Vera Lúcia Menezes de Oliveira e PaIva \\ (UFMG/CNPq/FAPEMIG) \\ Junia de Carvalho Fidelis Braga
}

(UFMG)

We should not only use the brains we have,

but all that we can borrow. (Woodrow Wilson)

\begin{abstract}
Drawing on Complexity Theory and on the literature of autonomy, the discussions herein presented will center around the language learner process of autonomy as a complex system. As empirical evidence to defend our assumptions, a corpus of 80 English language learning narratives, collected in Brazil, were examined and interwined with the theoretical discussion.
\end{abstract}

KEY-WORDS: Complexity; autonomy; foreign language learner.

RESUMO: Tendo a teoria da complexidade e a literatura sobre autonomia como suporte, apresentamos uma discussão sobre o processo de autonomia do aprendiz de língua estrangeira como um sistema complexo. Para defender nossa proposta, utilizamos como evidências empíricas, em diálogo com a discussão teórica, um corpus de 80 narrativas de aprendizagem de lingua inglesa, coletadas no Brasil.

PALAVRAS-CHAVE: Complexidade; autonomia; aprendiz de língua estrangeira.

\section{Introduction}

Autonomy first began to be addressed in the foreign language (FL) teaching field with the emergence of the communicative approach. Previously, autonomy was allowed no space within the classroom, considering that the teacher commonly controlled all learning activities and the students' rights were limited to the choices made by the school. 
In the seventies, with the emergence of a new concept of language language as communication - and the emphasis on the cognitive processes, autonomy appeared as a central feature in FL teaching. The communicative approach opened the door for more autonomous learners, although many factors, which will be discussed later, can still prevent autonomous learning experiences.

The concept of autonomy has become part of mainstream research and practice in Western cultures and appears to have become universally accepted as an important educational goal, as pointed out in the works of Benson (2001); Benson \& Voller (1997); Sinclair (1997); and Paiva (2006), who first attempted to understand autonomy in language learning as a complex phenomenon.

This chapter presents a complementary contribution which aims to analyze, in the light of complexity, the dynamics of the language learner's process of autonomy.

\section{The concept of autonomy}

One of the most well-known definitions of autonomy was reported by Holec (1981: 3), who considers autonomy to be "the ability to take charge of one's own learning". Another key contribution to autonomy was reported by Little (1991), who claims that "autonomy is a capacity for detachment, critical reflection, decision making, and independent action." For Little (1991), this capacity includes the planning, monitoring, and evaluating of learning activities and involves both the content and process of learning.

According to Paiva (2006), although the definitions from Holec and Little do touch a central aspect of the phenomenon, they do not take into account other factors, such as educational and economic contexts, which interfere in the learning process. In both cases, learners are treated as human beings who are free from internal and external influences, be they positive or negative.

Several other works, such as those from Dickinson (1987), Little (1991), Pennycook (1997), Benson \& Voller (1997), Benson (2001), Nicolaides \& Fernandes (2002), and Littlewood (1996) have also contributed to the discussions surrounding autonomy. Dickinson's work (1987: 27) approaches 
autonomy as "a mode of learning - one in which the individual is responsible for all the decisions connected with her learning, and undertakes the implementation of these decisions". In this aspect, Paiva (2006) points out that rarely will language learners have the ability to make and implement all the decisions concerning their learning, especially when one considers that learners, in most cases, will depend at least upon material written by other authors.

The assumptions presented by Holec (1981), Little (1991), and Dickinson (1987) represent the highest degree of autonomy, enabling the learner to choose what, how, and when to learn, with no external constraints, such as those of formal education. This idea is also present in Crabbe's (1993) ideological argument: "the individual has the right to be free to exercise his or her own choices as in other areas, and not become a victim (even if an unwitting one) of choices made by social institutions" (p. 443). This definition matches the etymological meaning of the expression - the "right of self-government" - as registered by the Oxford Dictionary of English Etymology (Onions, 1966). This is also the manner through which philosophy sees autonomy. "To be autonomous is to be a law to oneself; autonomous agents are self-governing agents", as pointed out by Buss (2002). For Young (1986), as referred to in Pennycook (1997), autonomy means "authoring one's own world without being subject to the will of others" (p. 35), while for Pennycook (1997) it is "the struggle to become the author of one's own world, to be able to create one's own meaning, to pursue cultural alternatives amid the cultural politics of everyday life" (p.39).

Candy (1989) defends the menace that formal education can represent to the learners' freedom to make their own choices. According to Candy (1991), the learners' own volition makes learning happen, and learning is seen as the result of one's own self-initiated interaction with the world.

Freire (1997) understands autonomy as the learner's capacity and freedom to construct and reconstruct the knowledge taught. Although the concept of freedom remains a core issue, Freire does not disregard the importance of the teachers whose role, in his view, is not to transmit knowledge, but to create new realms of possibility for students to produce and/or construct knowledge.

Freire (1970,1997), Young, (1986), Pennycook (1997), and Benson (1997) defend the idea of autonomy as a form of learner identity, i.e. 
autonomy as a right, implying the ability to take control of one's own learning process. This critical view of autonomy has the aim of social transformation as well as freedom to think and act in order to become the author of one's own world.

Based on a review of the literature on autonomy, Benson (2001: 2) claims that the "concept of autonomy is grounded in a natural tendency for learners to take control over their learning" and as such is available to all, although it may be displayed in different ways and to different degrees depending on the characteristics of each learner and each learning situation. Furthermore, the author argues that learners who lack autonomy are still capable of developing it if placed within the appropriate conditions and offered due preparation. Benson (2001) further emphasizes the fact that the way teachers organize the practice of teaching and learning will influence, both positively and negatively, the development of autonomy amongst students.

Benson (1997) suggests that three major versions of learner autonomy should be considered in the field of language learning: the technical, the psychological, and the political. Technically autonomous learners are those who are equipped with the necessary skills and techniques which enable them to learn a language without the constraints of a formal institution and without a teacher. The psychological version defines autonomy as the internal capacity to take responsibility for one's own learning, whereas the political version focuses on the "control over the content and process of one's own learning” (p. 25). According to the author, although the technical and psychological dimensions of autonomy may equip learners with the skills needed to manage their learning and instill confidence in the individual, they tend to reduce social problems to the level of the individual. In this respect, Sinclair (1997) suggests that autonomy encompasses social, individual, psychological, and political aspects and should be thought of as a concept which accommodates different interpretations, thus being more universally appropriate, rather than solely based on Western liberal values.

As Benson (1997) claims, autonomy is "a complex and multifaceted concept" (p.29). It consists of a variety of elements which render autonomy virtually impossible to be comprehensibly described by a single definition. In this sense, the technical, psychological, and socio-political issues pointed 
out in the literature may in fact serve as a useful starting point in the investigation of the relations between autonomy and language learning. In the view of complexity, the aforementioned versions are complementary and embrace elements or agents ${ }^{1}$ such as the learner (learning styles, motivation, responsibility for one's own learning, control of content, etc.), the teacher (atitude, pedagogical choices, etc.), the context (schools, econonomic factors, social experiences, etc.), and technology (communication tools, cultural artifacts, etc.), which together represent diversity in autonomy. In other words, these elements can be considered agents of a complex system because they interact within the system and with other systems in which they are nested, such as in eductional settings.

Based on this understanding, Paiva (2006) argues that autonomy is more than merely a matter of one's own responsibility for learning. Although it can be encouraged by teaching approaches as well as by teachers, autonomy is a complex phenomenon which emerges from the interaction of elements such as those mentioned above.

\section{Autonomy as a complex system}

Arising from the natural sciences, notions of complexity have been used for the comprehension of human and social systems. As highlighted by Morin (1990), human life is a phenomenon of self-eco-organization of extraordinary complexity and, therefore, the anthropo-social phenomena are unable to comply with principles of less complex intelligibility than those required for natural phenomena.

At first glance, complexity encompasses a great quantity of interactions and interference among a vast number of agents. However, complexity is not solely about the quantity of agents and interactions, but mainly about the interweaving of events, actions, interactions, retroactions, determinations, and random events that constitute our world (Morin 1990).

Complexity, a new approach to science, is still flourishing. As it develops, it becomes increasingly evident that it can be considered an alternative to linear and reductionist approaches, a new outlook which

1 Any element or factor which contributes to the evolution of the system. 
contemplates the diversity among the agents of a system, its relations, and the patterns that emerge from these relations.

The constant actions and reactions from agents of the system qualify them as complex. A complex phenomenon relies on other necessary qualities: it is dynamic, adaptative, self-organizing and emergent, unpredictable, nested, non-linear, open and sensitive to feedback and to the initial conditions and changes, to mention only a few of its core properties.

In that which regards the phenomena relative to the language acquisition process, Larsen-Freeman (1997:141) has already noted that "there are many striking similarities between the new science of chaos/ complexity and second language acquisition (SLA)". In discussing issues relative to interlanguage, individual differences, and the effects of instruction, Larsen-Freeman (1997) contends that in non-linear systems, such as second language learning, the behavior of the whole emerges from the interactions of the parts. Thus, by studying the parts in isolation, one by one, we will only be discussing each part as opposed to the manner in which the parts interact.

In this line, an ever-increasing number of articles have been analyzing the second language acquisition process, and the language learning classroom in general, in the light of chaos and complexity theories (LarsenFreeman 1997, 2000, 2006; Cameron 1999; Finch 2002; Paiva 2002, 2006, 2006b; Parreiras 2005; Braga 2007; Martins 2008 and Silva 2008).

Regarding autonomy, Finch (2002:17) understands that complexity theory is "offering a new description of the learning environment and providing further justification for the promotion of autonomy in language learning ${ }^{2}$. . In this direction, Paiva (2006) argues that autonomy is a sociocognitive system as it involves not only the individual mental states and processes, but also social dimensions if we view language as communication and not only as a set of linguistic structures. To learn a language, one must also use the language and develop autonomy as a communicator (see Littlewood 1996). The different degrees of independence and control will vary according to the individual characteristics and the socio-political

2 Although part 2.1 of his paper is named Complexity theory and autonomy, Finch does not refer to the theory to discuss what autonomy is. 
context. The aforementioned studies, which seek to better understand the phenomena of language learning and autonomy in educational contexts, appear to agree that the notions of complexity can serve as a system of interpretations geared toward a better understanding of the dynamics of systems that learn.

In this light, as previously mentioned, the agents which constitute an autonomous system interact among themselves with agents from other systems. From these interactions, emerge patterns, capable of positively or negatively influence the process of language learner autonomy.

These considerations agree with that reported by Paiva (2006) who states that input, the learner, the socio-political and economic context, the technology, the teacher, the educational contexts, among others, constitute some of the many factors inherent in the process of language learner autonomy. Autonomy is hereby understood as a process in constant movement, especially as regards the actions, reactions, and changes that occur over time.

Taking into account the notions of complexity, as well as some constraints which interfere in one's autonomy, Paiva (2006: 88-9) defines autonomy as:

a complex socio-cognitive system, subject to internal and external constraints, which manifests itself in different degrees of independence and control of one's own learning process. It involves capacities, abilities, attitudes, willingness, decision making, choices, planning, actions, and assessment either as a language learner or as a communicator inside or outside the classroom. As a complex system it is dynamic, chaotic, unpredictable, non-linear, adaptative, open, self-organizing, and sensitive to initial conditions and feedback.

A dynamic system continuously changes over time and the network of agents integrated into a dynamic whole also relies on the capacity to adapt its behavior to possible changes in environments, conferring upon the system an adaptive character.

These changes are considered to be non-linear as the effect is not necessarily proportional to the cause. They are chaotic because the system is apparently disordered, although there is an underlying order in this apparent disorder. Nothing is determined or predictable. Only a small 
change in the initial conditions can drastically change the long-term behavior of a system. Kirshbaum (2002) explains that

the unpredictability that is thus inherent in the natural evolution of complex systems then can yield results that are totally unpredictable based on knowledge of the original conditions. Such unpredictable results are called emergent properties. Emergent properties thus show how complex systems are inherently creative ones.

The systems are open as they exchange input or energy with the environment. New elements can enter or leave the system, and any element in the system influences and is influenced by many others. McGroarty (1998), for example, acknowledges these constraints within the educational system as regards language learning. According to McGroarty:

The objectives, goals, and activities associated with language teaching [similarly] constrain opportunities to learn, because they adhere to conventions arising from educational and institutional history rather from the contemporary experience of learners and teachers (p.613).

In addition, complex systems are nested, that is, they "unfold from and are enfolded in one another" (Davis 2007) ${ }^{3}$. Still, these types of systems are suceptible to changes resulting from feedback. According to Palazzo (2004), feedback triggers causes and effects on a system which can either expand or stabilize the system.

Another fundamental characteristic of a system is its capacity for natural selection and self-organization. "The organization emerges, spontaneously, from the disorder and does not appear to be guided by known laws of physics. In some way, the order emerges from multiple interactions among the component units" (Palazzo 2004: 4).

When agents in a system work individually, that is, with little or no interaction, what is gained is simply the accomplishment of tasks designated to it. However, when agents work interacting, something new and different may result; something that is more than the sum of individual results, a consistent pattern which arises from the interactions among the agents of a system. This consistent or global pattern, originating from local patterns of a determined adaptive dynamic system is commonly called emergence.

3 Communication at The Fourth Conference on Complexity Science and Educational Research, Vancouver, CA.2007. 
In addition to the properties, Davis \& Simmt (2003) and Davis \& Sumara (2006) argue that certain conditions are needed for complex emergence. Some of these conditions include: internal diversity, neighbor interaction and distributed control.

Internal diversity deals with the diverse characteristics of a system, be it a learner, a classroom, or an teaching institution. The manifested internal diversity, such as that produced by peers of different competences, can provide further incentive toward the capacity of a learning community. According to Wenger (1998), the presence of diversity is an indicator pointing out that the peers accept new ideas and challenges through differences in perspective.

Decentralized control is at the same time both a property and a condition in that a system evolves because decentralization allows for neighboring communication. Likewise, from the point of view of complexity, the dispersion of control fosters individual proactivity while at the same time enables the elements of a system to interact with its collective.

As for neighbor interaction, "agents of a system must be able to affect one another's activities" and must communicate as they come together in a grander unity. Moreover, neighbor interaction contributes to the emergence of collective possibilities. (Davis and Sumara, 2006: 142)

Based on this understanding, our hypothesis is that, in an educational context, the process of autonomy is constructed from a number of agents which interact amongst themselves as well as with agents from other systems, whose interactions may produce a positive or negative influence on the process of self-direction of the language learner. In addition, autonomy and the learning system are nested systems and rely on conditions such as diversity, distributed control, and interaction amongst neighbors for complex emergence.

\section{Methodology: Language Learning Histories (LLH)}

The study presented in this chapter uses narrative research as a methodolocigal approach to investigating the dynamics of the process of language learner autonomy in the light of complexity. 
Bruner (2002: 46) defines narrative as "a singular sequence of events, mental states, occurrences involving human beings as characters and actors." He defends that we were born into the world equipped "with a group of predispositons to interpret the social world in a particular manner and to act upon our interpretations," that is, equipped with that which he calls "aptitude for the meaning" (p. 69). Narrative is thus, for the author, a form of thinking, of organizing the human experience, of organizing the appreciation of oneself, of others and of the world in which we live.

Brunner's definition can be complemented by Todorov (1979: 138), who claims that an ideal narrative begins with a stable situation that any force may disturb. From this arises a state of unbalance. Through the action of a force guided in an inverse direction, balance is restored. The second form of balance is similar to the first, but the two are never identical.

The narratives of second language learning describe sequences of actions, mental states, educational events, personal experiences, beliefs, fears, desires, preferences, personal and institutional relationships, stable situations, disturbances, and unbalances characteristic of the learning process. Such data can provide researchers with rich insights into the intertwined psychological, technical, and social-political aspects of autonomy instantiated in the different individual and collective events of the complex process of language learning. The genre sheds light on the acquisition process upon revealing learning experiences that, generally, have not received due attention within the community of Applied Linguistics researchers. The individual comprehension of how a language is learned, in addition to revealing singular experiences, may in fact highlight common aspects in a series of stories and stimulate important insights regarding recurrent phenomena in language acquisiton, as is the case with autonomy.

Thus, considering that narrative research offers us rich data for a better comprehension of autonomy, we have selected 15 narratives, after a criterious reading of a corpus of 80 Language Learning Histories from the project AMFALE ${ }^{4}$. We adopted the categorical-content perspective of

\footnotetext{
4 The AMFALE Project [Aprendendo com Memórias de Falantes e Aprendizes de Línguas Estrangeiras (Learning with Speakers and Learners of English as a Foreign Language)] brings together researchers interested in language learning narratives. Several researchers from Brazil, Japan, and Finland have been collecting language learning histories and using them for different research purposes, including autonomy in language learning. So far there is a corpus of written and oral
} 
narrative research as described by Lieblich, Tuval-Marshiach and Zilber (1998). After choosing the relevant narratives, we selected the subtexts by setting apart all the sections of the story which deal with autonomous learning experiences. Then we tried to match them with the characteristics of the complex systems in order to defend our hypothesis.

\section{Empirical Evidence for autonomy and complexity}

The discussion presented in this section are organized according to some of the specific agents of the process of autonomy in language learning: the learner, the teacher, the context and technology

\section{The learner}

The analysis of one piece from LLH (1) reveals the interweaving of the components of the process of autonomy and its inter-relation with the learning system:

(1) Before starting studying English in the public school, I tried to learn English by myself at the age of 10 . I loved songs sang in English, but I had to find out what the lyrics were telling me. Accordingly, I used a small dictionary several times and made an effort to join the sentences with the purpose of comprehending every song that I used to like. I also tried hard to copy the singer's pronunciation of words and that helped me on identifying the same words in different songs.

In (1), the learner reports his/her passion for music, the main motivation behind learning English. Although taken from an informal context of learning, the motivation of the learner unleashes a series of actions of selfdirections actions, such as searching for words in the dictionary, practicing pronunciation, identifying words in songs, among others. These actions of self-direction are imbued by decisions, responsibility for own's own learning, independent action, control of the content of learning, essential requirements for the development of language learning. The weaved group of elements seems to show that the process of autonomy and the process of

narratives in Portuguese and in English. There is also a corpus of multimedia narratives written in English. Other contributors are welcome. For more information, please visit the web site (http:// www.veramenezes.com.amfale.htm).or contact Vera Menezes at vlmop@veramenezes.com. 
language learning are nested, that is, they unfold from and are enfolded within each other.

Another piece from the same narrative reveals that just as in informal contexts of learning, the process of autonomy in formal contexts, such as the lanaguage classroom, counts on common properties of complex systems:

(...) I was in the 7 th grade when I have my first formal English class. Although I was so excited about really studying English, I got somehow disappointed when I was told that the teacher would work just with grammar, reading and a little writing. Luckily, the teacher aimed to do more. She developed interesting projects, worked with pronunciation, used a lot of games, songs and videos. Her classes were nice, but something was missing for me. I did not want just to repeat words and sentences. I wanted to really speak English. The teacher used to ask us our opinion about a subject but comments were always in Portuguese. I wanted more.

I continued studying by myself and at school, until I got a wonderful opportunity: I started working as a receptionist in private language school. I could study for free as I was an employee there. I took a three years course there and, in my opinion, it had a lot to do with the communicative approach. Classes were very communicative and student-centered; varied materials were applied; there was a lot of interaction we were usually encouraged to express our point of view and give personal exemplification; (...)

This piece from (1) appears to reinforce that the process of language learner autonomy relies on the interaction of diverse elements, represented in this narrative by motivation, interaction with native language speakers, with cultural artefacts, as well as due to pedagogical questions (instructional design according to the tradition approach, instructional design according to the communicative approach). These interactions are inbued with common qualities of complex systems, such as, for examples, unpredictability, dynamism, self-organization, and emergence.

Concerning unpredictability, the learner reports his surprise upon noting the use of new activities in the classroom: games, projects, etc. when he had initially expected mainly the use of grammar and reading. The affective issues suffer a spontaneous self-organization. If, in the first moment, the learner becomes frustrated when told of the classroom grammar activities, the interaction with the new activities leads to a new order - the emergence of satisfaction. In addition to these changes, the constant actions of self-direction reflect the dynamism and adaptability of the process of autonomy from this language learner. 
It is important to note that both in the informal as well as in the formal environments of language learning, the learner seeks neighbor interation. These interactions may promote the construction of shared knowledge as well as the dispersion of control. The pieces "there was a lot of interaction" and "Classes were very communicative and student-centered" suggest that the interaction and the distribution of control can positively influence the process of construction of meaning in the context and of language learning.

One of the experiences from learners reported in (2) appear to be similar to that reported in (1):

(2) My first contact with English happened in 1987, when I was eleven years old. It was an English course in my neighborhood. Actually it was just an introductory course, really focused on basic English. The classroom activities followed a traditional method, by using non authentic materials, and teacher centered all the time. Then I went to high school, where English classes are simply awful. Every year the same subjects were taught to us, such as verb to be, negative forms, interrogative forms etc.

However, the sport I have been practicing from that period so far is full of English words and expressions, what made me more interested in English. In fact skateboard has been a 'catapult' to my English learning process. It is common to meet native English speakers in skateboard contests, so I had to communicate with them in order to comment the contest, or even about my turn in it, for instance. This first steps where then, related to communicative learning process, since real use of language was required in order to communicate. Slangs and jargons were used all the time, and I did not know what exactly they meant, but I could get their meaning through the context we were in. After that, my interest have increased in many aspects of English, such as music, art and sports, what is just the continuity of the process that I began with when I was a child.

In his report, the learner points out that his language learning experiences come from traditonal approaches. Classes were centered around the teacher and in both cases the teachers used a structural approach. Some common properties of complex systems can also be observed in that reported by this learner. The dynamism and the adaptability are represented by the changes in his process which began in the formal classroom, and soon after counting on opportunities of speaking English while practicing sports.

In the case of sports, the learner adapts to his new social practice and makes an effort to interact with other atheletes in English, to learn technical 
terms, etc. These interations motivate him to search for other learning experiences, as pointed out in the piece: "After that, my interest have increased in many aspects of English, such as music, art and sports (...)". These instances also reflect the active participation of this learner in his process of language acquisition.

In both reports, (1) and (2), the learners suggest that the opportunities of interaction or exchange of ideas play a key role in the process of language learning, as can be seen in the excerpts: "She developed interesting projects, worked with pronunciation, used a lot of games, songs and videos." (1) and "It is common to meet native English speakers in skateboard contests, so I had to communicate with them in order to comment the contest, or even about my turn in it, for instance"( 2), "Slangs and jargons were used all the time and I did not know what exactly they meant, but I could get their meaning through the context we were in."( 2)

In this line, the interaction with multiple sources of information may contribute to the diversity of the system, thus contributing to its dynamism and, consequently, to its evolution. These ideas are in accordance with the work of Braga (2007), which demostrates that, throughout the process of the construction of meaning, the learner interacts with peers of different competences. More skillful students, for example, help their peers with difficulties in dealing with issues regarding technology, content of texts, task instructions, etc. The constant mobilization of competence, together with other aspects of diversity, influence the dynamics of this process.

As is the case with (1) and (2), excerpts from (3) and (4) reflect the complexity of the process of language learner autonomy:

(3) (...) In 1989, however (yes, folks, I am almost as old as a dinosaur, but I still do not bite, ok?!), I started learning English by myself, reading the magazine "Speak Up", attending a distance short term course and exchanging letters with people from different countries. The problem was that I only practiced reading and writing; no listening, no talking at all, and such a procedure brought me some problems, some limitations, later on, when I decided to attend a "normal" course at a private English school.

(4) My teacher always asked us to translate the texts and also the vocabulary exercises at home. I must admit that I acquired a certain knowledge about the language, as well as vocabulary in those times, but I got to the conclusion that if $\mathrm{I}$ did not studied by myself I would not learn so much. Since I always liked studying languages, especially English, I used to have a different hobby: I used to read my 
bilingual dictionary every time I could and also translate the lyrics of songs that I liked in order to increase my vocabulary. I decided to watch films with subtitles instead of seeing those dubbed ones. I confess that now I hate dubbed films, whatever is the original language. I also used to listen to the songs in order to get the pronunciation of some words, what did not work very well because of the different pronunciation some words have in songs. I only took English classes regarding conversation when I attended to English I classes in 2000

The (3) demonstrates that being autonomous is not only a matter of being responsible for one's learning due to the fact that, depending on the context, it is difficult to find opportunities to develop oral skills. The students long for "communities of practice", which Murphey, Jin and LiChin (2005) call 'imagined communities' as proposed by Anderson (2006) communities to which students belong or aspire to belong to in the future.

By the same token, in (4), the learner felt that the school experience was not enough for him to acquire the language and developed his own strategies. Although one can question the efficiency of reading a bilingual dictionary, this student took control of his learning, planned what to do, and became accustomed to listening to authentic language by watching movies without subtitles. His autonomous behavior helped him become aware of some features of spoken discourse, such as pronunciation variation. Still, his actions of self-direction, coupled with his neighbor interactions, open the door to possibilities for new adaptations, new interactions, and new niches as well as highlight the emergence of new patterns, such as the improvement in his vocabulary and oral skills.

These questions reveal that the process of autonomy underlies the notion of interdependence. The learners in (3) and (4) seek interlocution in social practices to use the recently-constructed meanings.

In this sense, each system, be it a learner, a classroom, or a community, has its own operations, its own relations, as well as its own identity, dynamics which govern its interactions with other systems. As a system, it is selforganized, and its behavior arises from this process of interaction of its

\footnotetext{
5 Anderson proposes the substitution of the concept of nation for imagined communities and explains that it is imagined "because the members of even the smallest nation will never know most of their fellow-members, meet them, or even hear of them, yet in the minds of each lives the image of their communion" (p.6).
} 
agents, while on the other hand, it is constantly influenced by other systems. Considering complex systems (a system being aligned within a larger system), it possesses, paradoxically, a certain degree of freedom and dependency.

\section{The teacher}

The teacher may be a key agent in the development of a learner's autonomous system, but they may also represent obstacles to the evolution of this proccess. In our corpus, we can find reports of teachers who encourage learners to listen to music, to chat on the net, and to interact with peers inside and outside of the classroom. There are others who try to imprison students in rigid syllabus guidelines, forbiding them to use their own strategies, such as translation, or to take on non-linear routes when using textbooks. These attempts, in a certain way, may reduce the dynamism of the system.

The teacher may be qualified or non-qualified; authoritative; supportive; an advisor; a knower; a researcher; a facilitator; a consultant; a personal tutor; a helper; a counselor; a controller; a coach; a negotiator; among others. Moreover, in FL contexts, the teacher, who many times is the only FL speaker that the learner actually comes into contact with, may be a good or a poor language model. No matter which role the teacher plays in the language classroom, he or she may positively or negatively influence the learner's autonomy.

In our corpus of 80 LLHs, when teachers are mentioned, most narrators simply describe some of the teachers' actions in the classroom. There are much criticism and few moments of praise. As all the narrators are prospective teachers and have already studied Applied Linguistics, they are aware of the new trends in language teaching and usually complain that they have undergone teacher-centered experiences, as can be seen in the following example:

(6) My first contact with the English language was at year seven here in Brazil. The classes were very much teacher centered and based on the PPP method. It was very boring and I didn't have any interest in learning the language.

There are also those who observe that their teachers show no autonomy themselves and remain over-reliant on the textbook. 
(7) In high school I had a teacher called Beth, who did not do anything else but follow the book by the rules, which was reading the text, and memorizing some specific words for the quiz.

(8) The classes were mostly the same and most of my teachers woudn't change a comma in the lessons"

It is also not uncommon to find complaints about teacher attitudes in comparison to more rewarding experiences. In the following example, the student talks about one who did not share the stage with the students, but describe others who empowered the students with tasks to develop their communicative skills.

(9) She was kind of rude with us and she thought that she was the best, that she never commited a mistake; she was the center of the class. She did not motivate us and her activities were mainly to study grammar points.

(...) The teachers were great and they tried to motivate us as much as possible. The teachers taught us to interpret the social meaning of the choice of linguistic varieties and to use language with the appropriate social meaning for the different communication situations. They also used to teach us to understand some aspects of a culture ( people's beliefs and values) and the main purpose of their classes was to give us the competence to be able to communicate effectively in English and not the only purpose to have a grammatical competence.

The "good" teacher in these students' opinions seems to be the one who helps students develop their autonomy as communicators. This idea is repeated in the following excerpt:

(10) (...) when i was in high school, i had good classes of english... the teachers used to incentivate the students to speak and communicate (specially by doing pair work activities).

Nevertheless, teachers can inhibit student attempts to speak as described in (11). In the same LLH, the narrator talks about another teacher who is portrayed as one who gave support to the student's autonomy.

(11) My teachers used to correct me when I made my mistakes of pronunciation when I read a text; thus I didn't want to speak in the classes.

My teacher used to lend me extra books for reading just by pleasure and I practiced a lot of my English talking to myself, but I could not talk to somebody else, because I was always afraid of make mistakes in pronunciation and very insecure. 
At the university, things changed completely. The professor explained us that we also had to collect materials, practice lot of listening activities besides the ones we had to practice in class. The interaction in class motivated me and most of the students to talk a lot and the more we used to speak, the more we learned in terms of vocabulary, pronunciation, grammar, etc. She also advised us to leave grammar activities to do at home and bring doubts to class.

The most criticized aspects about teachers in the learner narratives refer to centralized control of the class, the little diversity of the activities, and the lack of activities that offer opportunities of interaction. The reports suggest that these aspects inhibit the language learning process and leave us with the idea that diversity, neighbor interaction, and the distributed control are necessary conditions for the evolution of the systems. In this manner, these conditions should be considered upon elaborating a pedagogical design if we are to desire the emergence of autonomy and linguistic development in the formal context of language learning.

These ideas align with Freire's (1997) assumption that by giving students opportunities to construct knowledge, teachers are creating realms of possibilities, both individual and colletive, as students may become both author's of their own world and of social transformation.

Teachers may influence the student's development of autonomy and, even when they do not play the expected roles, the interaction with other agents, together with an inner chaos, may urge the students to make their own decisions as a means through which to increase their learning processes.

However, the language classroom, here understood as a community of learning and social practice, should legitimize the diversity of agents learners, in this case - thus contributing to the mobilization of the compentences of all agents involved in this context. Each agent of a system, in interaction with its context, generates specific patterns responsible for the recycling of its diversity and, consequently, the diversity of the system in which it is nested.

\section{The context}

The context may foster autonomy or hinder it. There are macro and micro contexts ranging from the political and economical macro social 
contexts to the micro social and educational contexts, such as the school and the classroom.

Many questions can be asked about the context. In which country is the language being learned? What are the political relationships between this country and other English speaking ones? Do learners have access to English speakers with whom they can interact? Can they easily travel to foreign countries to practice the language? Is there any political or economic dependence within this relationship? Are there hard feelings or prejudice against the English speaking people? Are books and other materials easily imported? Does everyone have access to foreign language learning regardless of their social class? Are there any similarities between the native language and the foreign languages?

Political and economic contexts can present obstacles to autonomy. Non-democratic governments, for instance, can reduce opportunities for learners to be in touch with other English speaking cultures. Some cultures, for instance, do not allow women or "inferior" castes to study. In Brazil, poor students are not charged for textbooks in general, but FL materials are not included in the material list. If a teacher wants to use a book, students must pay for it. Learning a foreign language in Brazil is, in fact, a commodity for higher classes although it is an obligatory subject in high school curricula.

Some institutional context features which might interfere in the learning process include: the pedagogical project, class size, financial support to update materials and equipment, and investment in teachers' continuing education.

The schools can foster learner autonomy by offering students resource centers, good libraries, and computer assisted language activities. The philosophical and educational principles which provide the foundation for the school's pedagogical project may either open the door to autonomy or posit obstacles for more autonomous learners, as can be seen in the following excerpt (12):

(12) My trajectory into English territory started many years ago while I was following 7th grade class at a public school. The class was full, about 50 students in it. Because of militarism ideology or another stupid reason the boys and girls were separated in different classrooms and even corridors. So it is easy to imagine a large group of boys in plenty energy confined to a small room and even worse, restricted 
to a small and uncomfortable desk. Despite talking a lot, receiving hard punishment for small things and having no rights we had no voice to complain or say nothing against anything. We had to accept the rules as they were.

In Brazil, as in many EFL contexts, there are no free language courses, and learning material is expensive. As we can see in the following example, some students face economic dificulties, but many times these students appeal to their creativity and autonomy to overcome them. It is interesting to note that autonomy can, in fact, be the result of a non-favorable context, as in the situation described by this narrator:

(13) I have NEVER had formal instructions in English before enter the college. I studied in a school where English was taught from " 7 a série" on. But it was a public school and there was NO available English teachers at the time. The school staff kept telling us: "We are going to find you an English teacher, but while this does not happen, you are going to have "religion" classes to replace the English ones". I heard that discourse the " 7 a, $8^{\mathrm{a}}$ séries". When I started high school I thought this problem would be solved. But it was not. Hence I had no formal instructions before the college. When I decided to try "vestibular" I borrow one set of books and tapes (from CURSOS DE IDIOMAS GLOBO - CIG) and I studied by myself. The English test in "vestibular" for me was EXTREMELY hard. The things I got from CIG was not enough to cover the kind of test required in "vestibular". Well, but I passed vestibular and enter the college. It was in 1999.

The student in (13) belongs to a poor social sector. He attended a high school which substituted the English classes for religious ones, most likely because there was no English teacher available. Our narrator, however, "borrowed" some material and managed to learn enough of the English language to pass the university entrance examination.

The poor rarely travel and have little or no contact with foreigners ${ }^{6}$. The Internet is still widely unavailable in Brazilian public schools and most underprivileged students cannot afford a personal computer nor pay for an Internet link. Despite all these obstacles, there is still no reason to deny the students' right to learn a foreign language especially because no one has the ability to foresee each student's true future.

\footnotetext{
6 It is worth mentioning that some poor Brazilians go to the United States to work as maids, drivers, waiters, etc, and that a select few of them become English Teachers when they come back. The same happens with privileged youth who have the opportunity to go abroad in exchange programs.
} 
On the other hand, some initial conditions made a significant difference for some learners, as we can see in excerpt (14). The student's mother was herself an English teacher and our narrator had had the opportunity to interact with the language since she was a young child. Her environment not only offered her someone who spoke the language, but also a lot of material, opportunity to travel, and enrollment in an English course for children.

(14) My English learning experience is quite different since I started having contact with the language when I was very young, something like two/ three years old, that is because my mother is an English teacher, so she started teaching me songs, poems, verses, prayers, etc, in English. It was so exciting! I felt like me and my mother had this secret code language that only us could speak. For sure this early learning had a great role in my future motivation to learn more and more about that "code". My house was always full of English books and English materials in general, so when I was around 7, I started reading books and "teaching myself" with a didactic book called "Steps".

I joined an English school when I was 9 years old, it was called "New Way", and it had a fantastic environment, teacher were very well trained and we had a total emphasis in communication, both oral and written, I studied there till I was 18. This studies were essential to give me a communicative competence, specially the functional and sociolinguistic ones, since they made me aware of the language and its structure. When I was 11 I went to a trip in U.S, it was a great deal for me as I could see that I was really able to communicate with natives. I still remember how excited I was because I could ask for a map in Epcot Center!

The continuous inflow of input provided by the surrounding context stimulated her autonomous system. She decided to "teach herself" the language by reading a textbook, which represents a high degree of autonomy. In addition, she also displays autonomy as a language user when she mentions her communication with native speakers while travelling abroad.

The narrator in (15) had the chance to interact with Americans and Brazilians who spoke English. He also resorted to individual learning strategies (using a bilingual dictionary and making lists of words).

(15) I've never been in a classroom to learn English but I had hundreds of teachers. Virtually every American or Brazilian who knew more than me and with whom I came into contact was my teacher. I asked questions all the time and had a bilingual dictionary in my jacket pocket at all times. I also kept a list of words which I had difficulty remembering so that I wouldn't have to look them up again. My exposure 
to the language was pretty much the way Communicative Approach teachers try to expose students in the classroom: natural settings, real situations and everyday language and seldom using translation (especially after moving to Tulsa where I had no contact with Brazilians). Just as the Communicative Approach preaches I learned everything, from grammar to idioms and phrasal verbs, using them in real life settings.

The narrator's interaction with the context is the main source of his language acquisition as it emerges from the umpredictable opportunities to use the language.

As could be seen in these excerpts, the context is also complex and dynamic and continuously changes over time. Different students react differently to the context constraints and adapt themselves, constantly searching for alternatives to supply what their school has denied them. In examples (14) and (15), we can find autonomous learners who do not miss the chance to use the language. But learners do not react the same way under similar initial conditions. Less autonomous students refuse to take risks either because they are shy or because they find it difficult to adapt themselves to non-linear unpredictable language experiences provided by the context.

\section{Technology}

The use of technology can also contribute to the fostering of autonomy. Although good teachers can provide good courses with simple material, technology can also increase learning opportunities. Printed material, dictionaries, visual aids, radio, cable TV, movies, songs, newspapers and magazines, videos, computers, internet tools (chat, forum, learning platforms, etc), software, online resources, digital corpora, DVDs, CDroms, and language labs are examples of cultural artifacts which can empower learners in their attempt to become autonomous. As pointed out by Sandholtz, Ringstaff, and Dwyer (1997:176),

$[T]$ he benefits of technology integration are best realized when learning is not just the process of transferring facts from one person to another, but when the teachers' goals is to empower students as thinkers and problem solvers. Technology provides an excellent platform - a conceptual environment - where children can collect information in multiple formats and then organize, visualize, link, and discover 
relationships among facts and events. Students can use the same technologies to communicate their idea to others, to argue and critique their perspectives, to persuade and teach others, and to add greater levels of understanding to their growing knowledge.

The Internet has proved to be an effective vehicle for communication, but it would be a broad overstatement to assume that everyone in the world is connected to the web. Students with home Internet access can develop autonomy through the use of additional materials as well as seek opportunities for interaction.

On-line courses are also an excellent context in which to enhance autonomy. The manner through which students approach this experience can reflect their degree of autonomy. The following commentaries from English teachers in an on-line experience point out a few examples of different degrees of autonomy:

- The only thing I know about computers is to send and open e-mails. That's why I am terrified about your discipline.

- I'm very interested about this online course. I don't know much about computers. I hope I enjoy this course!

- I will do my best to deal with the computer, because I almost know nothing about it. I'm sure this course's being on line will help me a lot. It will take me some time to feel comfortable dealing with it, but for sure I'll get it.

The examples were ordered in such a way as to show how students' feelings vary from terror to hope and to certainty. They also show that, given the initial conditions (in this case, an online course), reactions are not proportional to the cause and that students react in different ways. In our examples, willingness, fear, and self-confidence are emerging affective issues which can possibly interfere in one's autonomy.

\section{Conclusion}

Autonomy, in the perspective of complexity, encompasses properties and conditions for complex emergence and is inextricably linked to its 
environment. In this article, we examined some instances of learners' autonomy in relation to the learners, teachers, contexts, and technology. We observed that language learners influence and are influenced by social practices, teacher constraints or stimulus, features of the contexts, and technology, in a constant movement of organization and reorganization. The process of interdependence of the agents of an autonomous system, in an apparent paradoxical relation, possesses a certain degree of freedom and dependency as well.

As implied in LLHs, in ideal language learning contexts, the learner agents are influenced by: their willingness for autonomy, their ability to share their achievements with other learners and borrow from them; teachers who are themselves autonomous and who offer the learners some choices concerning the learning activities and who accept their rights to question and to suggest changes in the route of the course; schools which are flexible enough to accept innovative experiences and which allow teachers and learners to be the authors of the educational process; technology which provides artifacts for teachers and learners to exercise their autonomy as persons, learners, communicators, and technology users; and, finally, a fair social, political and economic system which gives every learner good learning opportunities and every teacher good teaching conditions.

No learner is entirely free. Learners have their autonomy limited by several constraints, as discussed in this chapter. In formal contexts, autonomy cannot be seen as individualization, but as a possibility of sharing potentials. Teachers' roles should include a higher level of tolerance to avoid conflict with more autonomous learners so as to stimulate them to share their knowledge with their classmates instead of silencing them.

Teachers who recognize their students' autonomy must be prepared for a different kind of learning environment - less hierarchical, with more distributed power aiming at a balance between teachers' management and learners' autonomy.

As Benson and Voller (1997) explain:

[A]utonomous modes of learning imply a re-evaluation of the roles of both learner and teacher, the relationship between them, and the relationship of both to institutions of learning. These roles and relationships can be complex and are not reducible to simple expectations of behaviour or distribution of power (p.93). 
The LLHs also suggest that cultural artifacts function as agents capable of offering the necessary input for acquisition, contributing to autonomous learning without interference from the school system. This idea aligns with the thought of Davis \& Sumara (2006) who argue that the 'neighbors' that should interact one with another in a community geared toward learning, are the ideas, the questioning, and other means of representation.

Despite the fact that the reports demonstrate that some agents may inhibit learning processes, such as teacher-centered classes, didactic material geared toward only improving the structure of the language, and the lack of opportunities to interact, some learners adapt and organize themselves through interaction with other language speakers, native or peers, in other formal learning contexts; with cultural artifacts, such as magazines, books, internet; and with agents that can promote self-direction, such as willingness, motivation, taking responsibility for one's own learning, the control of the content and of the learning, among others, thus maintaining the system alive and constantly learning.

The use of the Internet has brought a new dynamic and decentralized learning context. The advancement of information technology has created worlds of distributed intelligence where students are interconnected with other students with different degrees of autonomy, all of whom have access to countless resources. This new context takes us back to our initial quotation and we can conclude by saying that being autonomous means "We should not only use the brains we have, but all that we can borrow (Woodrow Wilson)".

Recebido em maio de 2008 Aprovado em dezembro de 2008 E-mail:vlmop@veramenezes.com juniabraga@taskmail.com.br

\section{REFERENCES}

ANDERson, B. 2006. Imagined Communities: Reflections on the origin and Spread of Nationalism. London: Verso.

Benson, P \& Voller, P. (Eds.).1997. Autonomy \& Independence in language learning. London and New York: Longman. 
Benson, P. 1997. The philosophy and politics of learner autonomy. In: Benson, P \& Voller, P. (Eds.). Autonomy \& Independence in language learning. London and New York: Longman.

.2001.Teaching and researching autonomy in language learning. Harlow, England: Longman.

Braga, J. C. F. 2007. Comunidades autônomas de aprendizagem on-line na perspectiva da complexidade. Unpublished doctoral dissertation, Faculdade de Letras, Universidade Federal de Minas Gerais, Belo Horizonte, Brazil.

Bruner, J. 2002. Atos de significação. $2^{\mathrm{a}}$ ed. Trad. Sandra Costa. São Paulo: Artmed.

Buss, S. 2002. Personal Autonomy. In: Zalta, E. N. (Ed.). The Stanford Encyclopedia of PhilosophyI (Winter 2002 Edition) [On-line]. Retrieved November $25^{\text {th }}, 2004$, from http://plato.stanford.edu/archives/ win2002/ entries/personal-autonomy.

Cameron, L. 1999. The complex dynamics of language use on tasks. Retrieved November $25^{\text {th }}$, 2004, from http://www.education.leeds.ac.uk/ research/ljc_complang.pdf

Candy, P.C. 1989.Constructivism and the Study of Self-direction in Adult Learning. Studies in the Education of Adults, 21: 95-116. . 1991. Self-direction for lifelong learning: a comprehensive guide to theory and practice. San Francisco, CA: Jossey-Bass.

Crabbe, D. 1993. Fostering Autonomy from within the Classroom: the Teacher's Responsibility. System, 21 (4): 443-52.

Davis, B. \& Simmt. 2003. Understanding learning systems: mathematics teaching as complexity science, in Jornal for reaserch in Mathematics, 34, (2):137-167.

Davis, B.\& Sumara, D. 2006. Complexity and education: inquiries into learning, teaching, and research. Mahwah, N. J.: Lawrence Erlbaum. Dickinson, L. 1987. Self-instruction in Language Learning. Cambridge: Cambridge University Press.

Finch, A. 2002. Autonomy: Where Are We? Where Are We Going? JALT CUE-SIG Proceedings, pp. 15-2. Retrieved February $14^{\text {th }}, 2008$, from http://www.finchpark.com/arts/autonomy/index.htm

Freire, P. 1970. Pedagogia do Oprimido. Rio de Janeiro: Paz e Terra. . 1997. Pedagogia da Autonomia. Rio de Janeiro: Paz e Terra.

Holec, H. 1981. Autonomy and Foreign Language Learning. Oxford: Pergamon. (First published [1979], Strasbourg: Council of Europe.) 
KIRSHBAUM, D. 2002. Introduction to Complex System. Retrieved August $12^{\text {th }}$, 2004, from http://www.calresco.org/intro.htm\#eme

Larsen-Freeman, D. 1997. Chaos/complexity science and second language acquisition. Applied Linguistics. Oxford : Oxford University Press, 2 (18):141-165.

Larsen-Freeman, D. 2000. Second language acquisition and applied linguistics. Annual Review of Applied Linguistics, 20: 165-181.

. 2006. The emergence of complexity, fluency, and accuracy in the oral and written production of five chinese learners of English. Applied Linguistics, 27 (4): 590-619.

LitTle, David 1991. Learner autonomy 1: definitions, issues, and problems. Dublin: Authentik.

Lieblich, A.; Tuval-Mashiach, R. and Zilber, T. 1998. Narrative Research: Reading, Analysis and Interpretation. Thousand Oaks, CA: Sage.

LitTLEwood, W. 1996. "Autonomy": an Anatomy and a Framework. System, 24, (4): 427-435.

Martins, A.C. 2008. A emergência de eventos complexos em aulas on-line e face a face: uma abordagem ecológica. Unpublished doctoral dissertation, Faculdade de Letras, Universidade Federal de Minas Gerais, Belo Horizonte, Brazil.

McGroarty, M. 1998. Constructive and Constructivist Challenges for Applied Linguistics. Language Learning, 48 (4): 591-622.

Morin, E. 1990. Introdução ao pensamento complexo. Lisboa: Instituto Piaget. Murphey, T.; Chen, J.; \& CHEN, L. 2005. Learners' constructions of identities and imagined communities. (pp.83-100) In: P. Benson \& D. Nunan (Eds.). Learners' Stories: Difference and Diversity in Language Learning. Cambridge: Cambridge University Press.

Nicolaides, C \& Fernandes, V. 2002. Autonomia no ensino de LE: uma questão cultural. In: Paiva, V.L.M.O., Dutra, D; Mell, H.R. (Eds.). Anais do VI Congresso Brasileiro de Lingüística Aplicada. ALAB. [CD-ROM]

Onions, C.T. 1966. (Ed.). Oxford Dictionary of English Etymology. Oxford: Clarendon Press.

PaIVA, V.L.M. de O. 2002. Caleidoscópio: Fractais de uma oficina de ensino aprendizagem. Unpublished memorial, Universidade Federal de Minas Gerais, Brazil.

. 2005. Modelo fractal de aquisição de línguas. In: Bruno, F. C. (org.). Ensino-aprendizagem de línguas estrangeiras: reflexão e prática. São Carlos: Claraluz,. p. 23-36. 
Paiva, V.L.M. de O. 2006. Autonomia e complexidade. Linguagem e Ensino, 9 (1): 77-127. . 2006b Comunidades virtuais de aprendizagem e colaboração. In: Travaglia, L. C. Encontro na linguagem: estudos lingüísticos e literários. Uberlândia: UFU,. p.127-154.

Palazzo, L. 2004. Complexidade, caos e auto-organização. Retrieved October $4^{\text {th }}, 2004$, from http://www.comp.ufla.Br/ monserrat/isc/ Complexidade_caos_autoorganizaçao.html

PARreiras, V. 2005. A sala de aula digital sob a perspectiva dos sistemas complexos: uma abordagem qualitativa. $356 \mathrm{f}$. Unpublished doctoral dissertation, Faculdade de Letras, UFMG, Belo Horizonte.

Pennycook, A. 1997. Cultural Alternatives and Autonomy. (pp. 35-53) In: Benson, P \& Voller, P. (Eds.). Autonomy E Independence in language learning. London and New York: Longman.

SiLva, V. 2008. A dinâmica caleidoscópica do processo colaborativo de aprendizagem: um estudo na perspectiva da complexidade e do caos. Unpublished doctoral dissertation, Faculdade de Letras, Universidade Federal de Minas Gerais, Belo Horizonte.

SinClair, B. 1997. Learner Autonomy: the Cross Cultural Question. In: IATEFL Issues. N.139. Retrieved February $14^{\text {th }}$, 2008, from http:// www.iatefl.org/content/newsletter/139.php

Todorov, I. 1979. As estruturas narrativas. São Paulo: Perspectiva..

Wenger, E. 1998. Communities of practice: learning, meaning and identity. Cambridge, UK, Cambridge University Press.

Young, R. 1986. Personal autonomy: beyond negative and positive liberty. London: Croom Helm. 